\title{
A NEW INSTITUTIONAL ECONOMIC THEORY OF PROJECT MANAGEMENT
}

\author{
Ping YUNG \\ Curtin University of Technology, Kent Str., Bentley, Perth, Western Australia 6102 \\ E-mail:ping.yung@curtin.edu.au \\ Received 07 June 2012; accepted 06 November 2012
}

\begin{abstract}
The theories of project management are not well developed despite the existence of extensive literature on the topic. This paper derives a New Institutional Economic theory of project management. It is suggested that project management encompasses both the discipline of operational management and that of economics. The operational management part deals with optimization of project processes. The basic postulation of the economic part is that human beings will maximize their benefits under constraints. Constraints are converted to either price or cost to facilitate the application of the law of demand. Three examples are used to demonstrate how refutable hypotheses can be derived when changes in constraints lead to changes in behaviours. The functions of project management are discussed in the contexts of this theoretical framework. A synthesis with existing theories is also given.
\end{abstract}

Keywords: new institutional economics, project management theory, constraints, construction, economics, operational management.

JEL Classification: D02; D23; D24; M11; L74.

\section{Introduction}

This paper develops a New Institutional Economic theory of project management. The motivation comes from the confusing opinions on the theory.

On the one hand, there are claims that there is no coherent underlying theory of project management (Shenhar, Dvir 1996) and that the theory is implicit and obsolete (Koskela, Howell 2002). Indeed, Kloppenborg and Opfer (2002) had nothing to report on theory in their analysis of 3,554 research works on project management, spanning 40 years. The claim that there is no theory of project management annoyed J. Rodney Turner, who then attempted to develop a theory through a serious of editorials in International Journal of Project Management (IJPM) (2006a, 2006b, 2006c, 2006d).

On the other hand, there are extensive literature on project management, there are even journals dedicated to project management (e.g. IJPM and Project Management Journal), and there are numerous schools of thoughts or perspectives of project management. For 
instance, Bredillet, again in a serious of editorials of IJPM (2007a, 2007b, 2007c, 2008a, 2008b, 2008c), suggested nine schools of thoughts.

There are also arguments that there should not be just a theory, but some theories of project management, e.g. Morris (2002), and that different types of projects need different theories (Shenhar 2001). This has led to the research on the project typology (Lalonde et al. 2010; Shenhar, Dvir 1996).

As a result, a number of authors, e.g., Söderlund (2004), have called for more theoretical formations in the field of project management. Inspired by the fruitful developments of New Institutional Economics since 1960s, this paper attempts to make a contribution to the theory of project management from the New Institutional Economic perspective.

\section{Project management theories: a brief review}

There exist two main theoretical traditions in project management research, namely, the Task Perspective and the Organizational Perspective. The Task Perspective of project management is also known as "hard" perspective, while the Organizational Perspective is generally known as "soft" perspective, although the terms "hard" and "soft" have been used in a loose and ambiguous way (Crawford, Pollack 2004).

\subsection{Task perspective of project management}

The task perspective of project management theory focused on the planning and control mechanisms in project. It has its intellectual roots in the engineering science and applied mathematics. During the 1950s, network analysis and planning techniques, such as program evaluation and review technique (PERT) and critical path methods (CPM) formed the focus of development in project management (Crawford et al. 2006b). Later on, the increasing use of computers has given rise to a "second generation" of operations research devoted to computer applications and expert systems for project planning, control and risk analysis (Packendorff 1995).

Essentially, the task perspective of project management theory generally divides a project into 3 distinct stages, namely, development, implementation and termination (Pinto, Prescott 1990). The development phase is usually subdivided into conceptualization and planning stages (Packendorff 1995). These phases are always assumed to be sequential, and therefore the Task Perspective of project management theory can be described in terms of a theory of planning, a theory of execution and a theory of evaluation (Koskela, Howell 2002; Packendorff 1995).

The theory of planning assumes that works are clearly defined can be divided into a number of processes through, e.g. a Work Breakdown Structure (WBS) (Packendorff 1995). The theory assumes a causal relationship between action of management (planning) and the outcome (Koskela, Howell 2002). The theory of execution is similar to job dispatching in manufacturing (Koskela, Howell 2002). It basically involves setting up a project organization and dispatch or allocates the tasks. The theory of evaluation 
involves performance reporting and the lessons learned will be used to the correct the previous phases (planning or execution) (Koskela, Howell 2002).

This traditional task perspective of project management theory has been critiqued by several authors (Koskela, Howell 2002; Maylor 2001; Morris et al. 2000; Packendorff 1995). The major reason is that accepting and applying such orthodoxy does not eliminate project failures, nor does it guarantee project success (Williams 2004). Therefore, this approach to project management is increasingly being recognized as not being the full view, and not always even the appropriate view of the discipline (Morris 2002). As a result, alternative views were proposed to which we turn.

\subsection{Organizational perspective of project management}

The Organizational Perspective of project management has its intellectual roots in social science. Traces of organizational perspective of project management, including project organization structures, leadership and the role of human resource management, appeared in the 1960s and 1970s (Cicmil, Hodgson 2006; Packendorff 1995). The 1980s were typified by a focus on project organization, project risk, project front end, external influences, among others (Crawford et al. 2006b). While in the 1990s, project management has become a "multidisciplinary subject" (Winch 1996). This trend continued in 2000s, and we saw a growth in the amount of project work across different - if not most - industries (Hanisch, Wald 2011).

In essence, the organizational perspective looks into the process, governance, behavioural, cultural and political aspects in the project. The underlying assumption is that these aspects will affect project performance. There is, however, no consolidated or widely agreed theory on the organization perspective of project management.

Bredillet, with his colleagues Turner and Anbari, organized the literature on project management into nine schools of thoughts, namely, the optimization school, the modeling school, the governance school, the behaviour school, the success school, the decision school, the process school, the contingency school, and the marketing school (Bredillet 2007a, 2007b, 2007c, 2008a, 2008b, 2008c). The optimization school and arguably the success school are based on the task perspective. The modeling school encompasses both the task perspective and the organizational perspective. However, most other schools of thoughts, including the governance school, the behaviour school, the decision school, the process school, and the marketing school could be allocated to the organizational perspective.

Despite the abounding research works on the organizational perspective, there is no consolidated theory on it. Attempts have been made to apply economic theories into the study of governance and behaviours of people in project management. Notable examples include the application of Transaction Cost Economics (TCE) (Turner, Keegan 2001; Turner, Simister 2001; Winch 1989), Principal-Agent Theory (PA Theory) (Mahaney, Lederer 2010; Müller, Turner 2005; Turner, Müller 2003) as well as the corollary of Coase Theorem (Lai et al. 2008; Yung 2009; Yung, Lai 2008). 
A notable development in this perspective is the concept of projects as temporary organizations (Lundin, Söderholm 1995; Packendorff 1995; Pollack 2007; Turner, Müller 2003; Turner, Simister 2001). This concept was first propounded in Sweden, therefore it is sometimes known as "Scandinavian School" of project studies. In this school, a project is seen as a temporary organization, and action, instead of decision, is at the center of the theory (Lundin, Söderholm 1995). Based on this school of thought, Turner has attempted to develop a theory in a series of editorials, in which the nature of project, its governance of the functions of project management were discussed (Turner 2006a, 2006b, 2006c, 2006d). Unfortunately, instead of further developing the "actionbased" theoretical framework, later development in this school involves the application of Transaction Cost Economics (Turner, Keegan 2001; Turner, Simister 2001).

\subsection{Other perspective of project management}

Contingency Theories have been applied to both permanent and temporary organizations (Harnisch, Wald 2012). For instance, Shenhar (2001) insisted that different types of projects need different theories. This has led to the research on the project typology (Lalonde et al. 2010; Shenhar, Dvir 1996) and on the matching of management approach and leadership styles with project types (Crawford et al. 2006a; Müller, Turner 2007). Believing in this contingency theory of project management, Morris (2002) argued that the scope of project management is too broad to have a single theory.

In addition, the research on project management has been criticized as being not sufficiently empirical (Packendorff 1995). Some authors therefore advocated to research on what project managers actually do, proposing a "project-as-practice" approach (Blomquist et al. 2010; Cicmil et al. 2006).

\subsection{The way forward}

To summarize, although there are abundant research works on project management, the theories of project management could be generally categorized into a task perspective and an organizational perspective, and the theories have been underdeveloped and need more contributions. Therefore, a number of authors have called for more theoretical formations in the field of project management.

For instance, Söderlund (2004) stressed the need to develop various theories of projects in a similar tradition as has been within the broader field of management research. An UK research network called "Rethinking Project Management: Developing a New Research Agenda" suggested that "a new research network was needed to enrich and extend the field beyond its current intellectual foundations, and connect it more closely to the challenges of contemporary project management practice" (Winter et al. 2006). The directions proposed in this study indicated the trend towards more theory-based research.

Packendorff (1995) argued that projects are institutions and the application of New Institutional organizational theory in the study of projects is "an interesting research 
field for future exploration". This paper attempts to make a contribution to the theory of project management.

\section{NIE theory of project management}

This paper seeks to develop a New Institutional Economic framework of project management which can derive refutable hypotheses for empirical testing. It is, however, necessary to introduce some basic concepts first.

\subsection{Economics vs. engineering}

Economics as a science asks and answers the question "why". It is used to explain phenomenon, notably human behaviour, while engineering deals with "how". Does project management fall into economics or engineering?

The major job of the project manager is to make sure the project commence and complete within budget, on time and to specification. Therefore, project management inevitably involves optimization of project processes, which falls into industrial engineering or operation management. However, economic theories are essential as project management inevitably involve human decisions and behaviours. Therefore, we suggest that project management is a discipline that shall encompass both economics and engineering.

\subsection{Constraints}

Adam Smith argued that the selfishness of human beings leads to the functioning of economic system. The selfishness has been interpreted as "constrained maximization" since neo-classical economics. Constrained maximization postulates that human beings will maximize their benefits under the constraints. It has become a basic postulation of neoclassical economics. New Institutional Economics does not confront with neo-classical economics. It merely introduces some constraints that were ignored in the latter.

There are as many types of constraints as one may imagine. However, following Steven Cheung (2002a), constraints can be broadly divided into eight categories, namely, wealth, price, knowledge, cost, law of diminishing marginal productivity, competition, property rights, and transaction costs. We shall add two further categories, namely, risk and time.

The first two constraints, i.e., wealth and price, are related to consumption. We follow Irving Fisher's definitions of wealth. Everything that can generate income is capital asset. Wealth is the discounted present value of all incomes. Price is the exchange value of a good. In equilibrium, it will equal to the maximum marginal use value of a consumer. The following three, i.e., knowledge, cost, and the law of diminishing marginal productivity, are related to production. Knowledge refers to the theoretical or practical understanding of a subject. Cost is the highest-valued opportunity necessarily forsaken. The law of diminishing marginal productivity says if there are two factors of production, 
e.g. land and labour, one increases and the other remains constant, the total products will increase but the rate of increase will diminish.

The last three, i.e., competition, property rights and transaction costs only appear in a society. The latter two were introduced in New Institutional Economics. Competition happens because economic goods are scarce and demanded by more than one people. Property rights are rules of the game. As people compete, there must be rules to determine who wins. The rules include the legal system that helps establish and maintain the rules. The rules may be price (if you can pay, you get the goods), ranks in the society (as in communist China), etc.

Transaction costs refer to the costs of negotiating and enforcing the stipulations of the contract (Cheung 1969; North 2000). North (2000) added that the cost of transacting is the cost of specifying and measuring the characteristics of what is being exchanged and the cost of enforcing agreements. However, Cheung (1998) argued that transaction costs must be defined to be all the costs which do not exist in a Robinson Crusoe economy and should actually be called "institution cost".

Risk is the effect of uncertainty on objectives. Many risks arise because of transaction costs (of information or enforcing contracts). Nonetheless, some risks exist even without any institutional costs. Time is the specified deadline before which a contracted task must be performed. Neo-classical theories have assumed all transactions are instantaneous. However, in the engineering field, usually time is of essence.

\subsection{NIE theory of project management}

To summarize, we opine that project management is a discipline that encompasses both operational management and economics. On the one hand, project management involves optimization of project processes. This falls into the discipline of operational management. On the other hand, the complex processes involve human behaviours that fall into the discipline of economics. The NIE framework has a basic postulation that human beings will maximize their benefits under constraints. These constraints can be broadly divided into ten categories. When the constraints change, human behaviours will change which will be observable. In other words, our theoretical framework can generate empirically testable hypotheses, thereby fulfilling the requirements of being a theory. We shall demonstrate this by using three examples in the later sections.

Basically, a lot of constraints could be converted into the constraints of cost, then the law of demand could be applied. The difficulty of this theoretical framework lies in the clear understanding of the constraints, as constraints are real world phenomena which should not and cannot be imagined. For now let us have a deeper understanding of this theoretical framework by a discussion on the functions of project management.

\section{Functions and constraints of project management}

In this section, we shall discuss the functions of project management in the context of our new NIE framework. It has been found that in project management the most 
frequently addressed industry was construction (Betts, Lansley 1995; Pinto, Slevin 1988; Themistocleous, Wearne 2000). As a result, we shall use construction project management as an example, although the theory is intended to be general.

\subsection{Functions of project management}

The project life cycle usually consists of the following stages: conceptualization, planning, execution and termination. In the conceptualization stage, alternatives and their feasibilities are studied and finally desirable outcomes and possible outputs are identified. In the planning stage, the concepts in the previous stage is refined, and the means of achieving them is defined. In the execution stage, the outputs are processed. In the termination stage, the outputs are commissioned and delivered to the client. The function of project management is to optimize the whole process. We shall discuss in more detail below.

The Project Management Body of Knowledge (PMBOK) suggests nine knowledge areas, namely, project integration management, scope management, time management, cost management, quality management, human resource management, communication management, risk management and procurement management (PMI 2000). The functions of project management are to make sure all these nine areas of management are properly done. The first area, namely, project integration management, is simply making sure all other processes are properly done. Other areas, however, need detailed discussion.

Scope management \& quality management. The project is usually divided into phases such as design, tender and construction. Each phase could be regarded as a "subproject". Scope Management and Quality Management are "outsourced" by contract to the "manager" of each phase. The project manager makes sure scope \& quality is managed in each phase. He needs to make sure the following 3 matters:

a. An architect will manage the scope and quality in the design stage, and

b. The requirements on scope and quality is properly documented in the tender stage, and

c. A construction manager from the contractor will manage the scope and quality in the construction stage, and an architect or a contract administrator will check the compliance of scope and quality.

Time management. The project is divided into phases such as design, tender and construction. The client contracts with an architect, a quantity surveyor (QS) and a contractor in each phase. Time will be a condition in each contract so that if the other party is late in delivering the required output, he has to pay damages to the client. Therefore, the requirements on time are usually converted into costs.

Cost management. The project is divided into phases such as design, tender and construction. A major part of cost management work is "outsourced" by contract to a QS. The project manager needs to make sure the following tasks will run smoothly:

a. In the conceptualization stage, the QS will establish a budget and agree it with the client. 
b. In the design stage, the QS will prepare cost plans to make sure the design is within budget, the architect needs to amend the design if cost is over the budget. This process may repeat a few times.

c. In the tender stage, the QS will recommend a procurement strategy including the selection of contracts, e.g., the use of a lump sum contract, so that cost can be controlled.

d. A contract manager from the contractor will manage the cost of the contractor so that they will not make a loss.

Human resource management. Project staffs are either within or without the same firm of the project manager. If the staffs are within the same firm, the project manager may not have the authority to terminate the employment contract. In this case, other management skills such as leadership are relevant.

If they are outside the firm, their services must be purchased through contracts. The project manager needs to ensure their performance can be properly measured and ideally be linked to the payment. According to Steven Cheung (2002b), the monitoring costs (one type of transaction costs) will be lower if the aspect of performance is measured and priced. Therefore, when an architect is contracted for provision of design, the monitoring cost will be lower in the case that we only pay upon completion of the design to a certain detail, than in the case that we pay him according to the time he spends.

Communications management. Communication management in projects is done explicitly and implicitly. On the one hand, there are formal and informal meetings and written communications such drawings, instructions, etc. On the other hand, institutions are formed to act as coordination mechanisms (Kadefors 1995). These institutions include well-known procurement methods, e.g. traditional lump sum method, re-measurement method, etc.; tendering system; standardizations of, e.g., work processes, output, skills and knowledge, contract forms, etc. As Kadefors (1995) pointed out, the need for communication is reduced if the tasks and roles are standardized, as the participants then know what behaviour to expect from those performing independent tasks.

Therefore, the role of project manager in communication management is twofold. First, he must plan and coordinate regular meeting and the timely distribution of written documents. Second, he must make use of the institutions formed in the industry, as it is very difficult to change institutions once they are formed.

Risk management. Risk is an uncertain event or condition, that if it occurs, has a positive or negative effect on a project objective (PMI 2000). Risk management involves identification, quantification and ranking, responses strategies and monitoring and controlling. Risks are either avoided, or transferred, or mitigated or accepted. These involve change of plan, use of contracts such as insurance or lump sum contracts, etc. The role of project manager is to make sure this process is conducted properly.

Procurement management. This includes the procurement of both services and materials. In both cases contracts are involved. Procurement of materials is easier, while the contracts for services are more complicated as it involves the definition, measurement, monitoring and pricing of services. The same theory applies here: the monitoring costs 
will be lower if the aspect of performance is measured and priced (Cheung 2002b). In construction, a quantity surveyor will usually provide advice on procurement.

Having discussed the functions of project management, we now turn to the analysis of constraints faced in the parties involved. After all, the analysis of constraints is the most difficult part in the application of this theory.

\subsection{Constraints}

We shall discuss the constraints in details and show that constraints are often related and that in many cases other constraints can finally be converted into the constraint of cost.

Price is obviously a constraint. The law of demand is simply the most useful theory in microeconomics. Cost is obviously another constraint. For instance, if the client does not specify the materials for the walls which could be made of either brick or timber, and if timber is cheaper, the contractor will choose to use timber to build the walls. Constraints discussed below could actually be converted into the constraint of cost in many cases.

Wealth is a constraint. Large contractors usually own more plant and machinery. Smaller one, constrained by wealth, may need to hire plant and machinery. Where they are not available for hire, they may need to substitute them with labours, which might cost more. Hence, the constraint of wealth might be converted into that of cost.

Knowledge is a constraint. If depth of foundation is estimated wrongly because of lack of knowledge, it may end up with a collapsed building which will be costly. In addition, freshmen in a trade may need a lot of training to gain the necessary skills. If they are required nevertheless in case of shortage of labour, higher training costs and lower productivity will happen, and these increase the cost.

A producer will face the constraint of the law of diminishing marginal productivity. For instance, a contractor needs to speed up the construction for whatever reasons. Suppose both plant and labours are required to do the job, e.g., excavation of trenches for the foundation. If for some reasons one of the factors of production cannot be increased, e.g. the maximum number of plant (excavator) is two due to the limitation of space, increasing the other factor of production, i.e., labour, will increase the total product, but at a decreasing rate, till a point when the total product reaches maximum and then goes down. The implication of this constraint is actually on costs as lower productivity means higher costs.

Competition is a constraint. When we make contracts, we would not worry about extremely high prices as we know there are competitions from a lot of potential suppliers.

Specialization and exchange dramatically improve productivity. This wisdom was established by Adam Smith (he called it division of labour). While classical economists David Ricardo and John Mill opined that comparative advantage is the reason for specialization, Steven Cheung (1998) argued that in addition to that, accumulation of knowledge is more important. Therefore, we see people specialize in one trade or another. In construction, workers also specialize. Therefore we will need a team of tradesmen including, e.g., concreter, brick layer, roofer, glazier, plumber, electrician, etc. 
When we want to ask these tradesmen to work for us, we contract with them. This inevitably involves the property rights system, e.g. are we free to contract with them? In communist China, resource allocation and income distribution were all performed by the government. A contractor, who was necessarily the most efficient one, would be designated by government officers (this seldom happens today). If that is the case, the rules of competition will be different from price mechanism with which economists are familiar. It will be difficult to negotiate and enforce any requirements of the project, i.e. transaction costs in this system are much higher.

Property rights include the rules of law, customs, etc. Therefore, when a law changes the rule of completion, we shall observe changes in behaviours (see examples in next section).

Now suppose we have private property rights system that is common in most developed countries. Transaction costs arise when we contract. We choose to contract because the benefits from specialization and exchange are greater than the transaction costs. Under the postulation of constrained maximization, people will minimize the transaction costs to gain the benefits of specialization and exchange. This explains the popular use of standard forms of contracts in construction industry.

Risk is a constraint. We can avoid, mitigate, transfer or accept the risks. When we avoid or mitigate risks, we change our behaviours which will be observable and may have impacts on costs. When we transfer the risks, by e.g. insurance or by contracts, the parties now bearing the risks will charge a premium which acts to our costs. However, because of competition, they can only charge at a market rate. When the risk is too trivial, we accept it and do nothing.

Time is a constraint. A construction contract usually specify the period within which the works must be completed. If a contractor fails to complete before the specified completion date, he needs to pay a "liquidated damage" to the client which is a genuine pre-estimate of the likely loss suffered by the client. In this way, time constraint is converted to cost.

The constraints of property rights and transaction costs are the two most difficult constraints for analysis as it requires deep understanding of the subject matter. We shall therefore demonstrate how changes in these two constraints could lead to changes in behaviours in the next section.

\section{Some applications}

We could derive refutable hypothesis when the constraints change. We shall convert the constraints into the constraint of cost and then apply the law of demand to make testable hypothesis. Below are three examples.

H1: If the law puts the burden of construction safety on the contractor such that the contractor needs to compensate when a worker dies, the safety performance of contractor will improve.

This hypothesis deals with the changes in the constraint of property rights (the laws). As the law puts the burden on the contractor, the price for the contractor to provide a 
safe working environment becomes lower, because the price now equal to the cost of providing a safe working environment minus the expected savings on compensations to the workers. According to the Law of Demand, as the price goes down, the contractor will tend to provide a safer working environment and therefore the safety performance will be improved. The empirical evidence was documented in Yung (2009), although how the changes in constraints lead to observable behavioral change was not made clear in that paper.

H2: If the law mandates that construction quality shall be supervised by independent construction supervisors, the quality performance of contractor will improve.

This hypothesis again deals with the changes in the constraint of property right (the laws). As the construction quality is now supervised by an independent construction supervisor, any work with poor quality might have to be demolished and reconstructed. Therefore, the price of providing good quality work becomes lower, as the price is now equal to the cost of providing good quality work minus the expected savings in the possible demolition and rework. According to the Law of Demand, as the price goes down, the contractor will tend to provide better quality works and therefore the quality performance will be improved. The empirical evidence was documented in Yung and Lai (2008), although how the changes in constraints lead to observable behavioral change was not made clear in that paper.

H3: construction works procured with "cost plus percentage or fixed fee" method will be more expensive than those procured with lump sum method, other things being equal.

This case deals with the transaction cost of monitoring efficiency. According to Cheung (2002b), the monitoring costs (one type of transaction costs) will be lower if the aspect of performance is measured and priced, because measurement itself constitutes monitoring. There are several established procurement methods for construction works, e.g., lump sum based on bills of quantities, cost plus etc. In a building contract, what the client wants to buy from the contractor is the materials, labours, plant use and the efficiency of performance. In a lump sum contract, all these aspects are measured and priced. The most efficient contractor will be chosen because he can offer the lowest price, and he has to work efficiently as he also faces the constraint of cost. However, in a cost plus contract, all the costs of the contractor, including materials, labours, and plant use, will be paid plus a fee to cover the contractor's overhead and profit. This method, however, failed to consider the efficiency of the contractor. Therefore, it will be more costly to monitor the efficiency of the contractor, and the latter tends to work less efficiently. Indeed, in the arrangements of cost plus percentage fee and cost plus fixed fee, the more inefficient the contractor is, the more he gets paid.

\section{A synthesis with existing theories}

We opine that project management has both the component of operational management and the component of economics. Therefore, our theory encompasses both the Task Perspective and the Organizational Perspective of project management. On the one hand, 
projects are practice which needs to be conceptualized, planned and executed. Therefore, it has an engineering component. On the other hands, projects must be performed by humans, the behaviours of which fall into the discipline of economics.

The study of project success factors and criteria has been very popular in the literature of project management. Indeed, it was classified as a school of thought (Bredillet 2008a). However, it has been found that the lists of success or failure factors vary in various studies (Belassi, Tukel 1996). It is also found that critical success factors (CSFs) differ in different project stages (Pinto, Slevin 1988) and as project objectives change (Chua et al. 1999). Therefore, the CSFs identified in one project may not be applicable to other projects. These findings are in some way consistent with the research on project typology which advocates that different types of projects need different management approaches.

Our interpretation of the above findings is that the constraints are different in different projects, and therefore people will have different behaviours under different constraints. Therefore, our theory is also consistent with the "success school" of research and the project typology research. Further researches could be directed to interpretation of the success criteria found in the literature with our theory.

Application of our theory is, however, not easy. It requires the researcher to investigate the actual constraints faced in the project, especially the constraints of property rights and transaction costs. Our emphasis is that theories must be refutable. Constraints are real world matters, one should not simply think of a few constraints in the office and avoid the challenge of empirical testing. Therefore, the application of this theory requires deeper understanding of project actuality. Hence, our theory is in some way consistent with the "project-as-practice" approach (Blomquist et al. 2010; Cicmil et al. 2006), although our theory has a thorough theoretical background.

\section{Conclusions}

This paper has developed a New Institutional Economic Theory of project management. The motivation has been the confusing opinions on the theories of project management. We suggested that project management is a discipline that encompasses both operational management and economics. On the one hand, project management is a professional practice that seeks to optimize the processes of project. This part is consistent with the traditional Task Perspective of project management. On the other hand, project management deals with human behaviours which fall into the discipline of economics. This part is consistent with the Organizational Perspective of project management.

In summary, we have developed a theoretical framework capable of developing refutable hypotheses to study project management. We have demonstrated how functions of project management are performed with the example of construction project management, although our theory is intended to be generally applicable. We have shown how scope, cost, time, quality, human resources, information, procurement, and risks are 
managed in construction project management. We have also shown a few examples how refutable hypotheses could be derived from our theoretical framework. Essentially, when the constraints change, we will observe changes in behaviours. We have shown that changes in constraints in many cases could be converted into changes in costs, thereby enabling the application of the law of demand. Therefore, our theory is empirically testable. We have also given a synthesis with existing theories.

\section{References}

Belassi, W.; Tukel, O. I. 1996. A new framework for determining critical success/ failure factors in projects, International Journal of Project Management 14(3): 141-151.

http://dx.doi.org/10.1016/0263-7863(95)00064-X

Betts, M.; Lansley, P. 1995. International Journal of Project Management: a review of the first ten years, International Journal of Project Management 13(4): 207-217.

http://dx.doi.org/10.1016/0263-7863(95)00001-7

Blomquist, T.; Hällgren, M.; Nilsson, A.; Söderholm, A. 2010. Project-as-practice: in search of project management research that matters, Project Management Journal 41(1): 5-16.

Bredillet, C. 2007a. Exploring research in project management - nine schools of project management research (Part 1), Project Management Journal 38(2): 3-4.

http://dx.doi.org/10.1002/pmj.20001

Bredillet, C. 2007b. Exploring research in project management: nine schools of project management research (Part 2), Project Management Journal 38(3): 3-5.

http://dx.doi.org/10.1002/pmj.20001

Bredillet, C. 2007c. Exploring research in project management: nine schools of project management research (Part 3), Project Management Journal 38(4): 2-4.

http://dx.doi.org/10.1002/pmj.20025

Bredillet, C. 2008a. Exploring research in project management: nine schools of project management research (Part 4), Project Management Journal 39(1): 2-6.

http://dx.doi.org/10.1002/pmj.20030

Bredillet, C. 2008b. Exploring research in project management: nine schools of project management research (Part 5), Project Management Journal 38(2): 2-4.

Bredillet, C. 2008c. Exploring research in project management: nine schools of project management research (Part 6), Project Management Journal 39(3): 2-5.

http://dx.doi.org/10.1002/pmj.20073

Cheung, S. N. S. 1969. Transaction costs, risk aversion, and the choice of contractual arrangements, Journal of Law and Economics 12(1): 23-42.

Cheung, S. N. S. 1998. The transaction costs paradigm, Economic Inquiry 36: 514-521.

http://dx.doi.org/10.1086/466658

Cheung, S. N. S. 2002a. Economic explanation book II, the behaviour of supply. Hong Kong: Arcadia Press.

Cheung, S. N. S. 2002b. Economic explanation book III, the choice of institutional arrangements. Hong Kong: Arcadia Press.

Chua, D. K. H.; Kog, Y. C.; Loh, P. K. 1999. Critical success factors for different project objectives, Journal of Construction Engineering and Management 125(3): 142-150.

http://dx.doi.org/10.1061/(ASCE)0733-9364(1999)125:3(142)

Cicmil, S.; Hodgson, D. 2006. New possibilities for project management theory: a critical engagement, Project Management Journal 37(3): 111-122. 
Cicmil, S.; Williams, T.; Thomas, J.; Hodgson, D. 2006. Rethinking project management: resesarching the actuality of projects, International Journal of Project Management 24: 675-686. http://dx.doi.org/10.1016/j.ijproman.2006.08.006

Crawford, L.; Hobbs, J. B.; Turner, J. R. 2006a. Aligning capability with strategy: categorizing projects to do the right projects and do them right, Project Management Journal 37(2): 38-50. http://dx.doi.org/10.1016/j.ijproman.2004.04.004

Crawford, L.; Pollack, J.; England, D. 2006b. Uncovering the trends in project management: journal emphases over the last years, International Journal of Project Management 24: 175-184. http://dx.doi.org/10.1016/j.ijproman.2005.10.005

Crawford, L.; Pollack, J. 2004. Hard and soft projects: a framework for analysis, International Journal of Project Management 22: 645-653.

Hanisch, B.; Wald, A. 2011. A project management research framework integrating multiple theoretical perspectives and influencing factors, Project Management Journal 42(3): 4-22.

http://dx.doi.org/10.1002/pmj.20241

Kadefors, A. 1995. Institutions in building projects: implications for flexibility and change, Scandinavian Journal of Management 11(4): 395-408. http://dx.doi.org/10.1016/0956-5221(95)00017-P

Kloppenborg, T. J.; Opfer, W. A. 2002. The current state of project management research: trends, interpretations, and predictions, Project Management Journal 33(2): 5-18.

Koskela, L.; Howell, G. 2002. The underlying theory of project management is obsolete, in Proceedings of PMI Research Conference, 2002, 293-302.

Lai, L. W. C.; Ng, F. W. N.; Yung, P. 2008. The Coase Theorem and a Coasian construction economics and management research agenda, Construction Management and Economics 26(1): 29-46. http://dx.doi.org/10.1080/01446190701450438

Lalonde, P. L.; Bourgault, M.; Findeli, A. 2010. Building pragmatist theories of PM practice: theorizing the act of project management, Project Management Journal 41(5): 21-36.

http://dx.doi.org/10.1002/pmj.20163

Lundin, R. A.; Söderholm, A. 1995. A theory of the temporary organization, Scandinavian Journal of Management 11(4): 437-455. http://dx.doi.org/10.1016/0956-5221(95)00036-U

Mahaney, R. C.; Lederer, A. L. 2010. The role of monitoring and shirking in information systems project management, International Journal of Project Management 28: 14-25.

http://dx.doi.org/10.1016/j.ijproman.2009.03.001

Maylor, H. 2001. Beyond the Gantt chart - project management moving on, European Management Journal 29(1): 92-100. http://dx.doi.org/10.1016/S0263-2373(00)00074-8

Morris, P. W. G. 2002. Science, objective knowledge, and the theory of project management, in Proceedings of the Institution of Civil Engineers: Civil Engineering 150(2): 82-90.

http://dx.doi.org/10.1680/cien.2002.150.2.82

Morris, P. W. G.; Patel, M. B.; Wearne, S. H. 2000. Research into revising the APM project management body of knowledge, International Journal of Project Management 18(3): 155-164. http://dx.doi.org/10.1016/S0263-7863(99)00068-X

Müller, R.; Turner, J. R. 2005. The impact of principal-agent relationship and contract type on communication between project owner and manager, International Journal of Project Management 23: 398-403. http://dx.doi.org/10.1016/j.ijproman.2005.03.001

Müller, R.; Turner, J. R. 2007. Matching the project manager's leadership style to project type, International Journal of Project Management 25: 21-32.

http://dx.doi.org/10.1016/j.ijproman.2006.04.003

North, D. C. 2000. Understanding institutions, in C. Menard (Ed.). Institutions, contracts, and organizations: perspectives from new institutional economics. Cheltenham, UK: Edward Elgar Pub. http://dx.doi.org/10.4337/9781781952764.00011 
Packendorff, J. 1995. Inquiring into the temporary organization: new directions for project management research, Scandinavian Journal of Management 11(4): 319-333.

http://dx.doi.org/10.1016/0956-5221(95)00018-Q

Pinto, J. K.; Prescott, J. E. 1990. Planning and tactical factors in the project implementation process, Journal of Management Studies 27(3): 305-327.

http://dx.doi.org/10.1111/j.1467-6486.1990.tb00249.x

Pinto, J. K.; Slevin, D. P. 1988. Critical success factors across the project life cycle, Project Management Journal 19(3): 68-75.

PMI. 2000. A guide to the project management body of knowledge. Pennsylvania: Project Management Institute.

Pollack, J. 2007. The changing paradigms of project management, International Journal of Project Management 25: 266-274. http://dx.doi.org/10.1016/j.ijproman.2006.08.002

Shenhar, A. J. 2001. One size does not fit all projects: exploring classical contingency domains, Management Science 47(3): 394-414. http://dx.doi.org/10.1287/mnsc.47.3.394.9772

Shenhar, A. J.; Dvir, D. 1996. Toward a typological theory of project management, Research Policy 25: 607-632. http://dx.doi.org/10.1016/0048-7333(95)00877-2

Söderlund, J. 2004. Building theories of project management: past research, questions for the future, International Journal of Project Management 22: 183-191.

http://dx.doi.org/10.1016/S0263-7863(03)00070-X

Themistocleous, G.; Wearne, S. H. 2000. Project management topic coverage in journals, International Journal of Project Management 18(1): 7-11.

http://dx.doi.org/10.1016/S0263-7863(99)00030-7

Turner, J. R. 2006a. Editorial: towards a theory of project management: the functions of project management, International Journal of Project Management 24: 187-189.

http://dx.doi.org/10.1016/j.ijproman.2006.03.001

Turner, J. R. 2006b. Editorial: towards a theory of project management: the nature of the functions of project management, International Journal of Project Management 24: 277-279.

http://dx.doi.org/10.1016/j.ijproman.2006.03.002

Turner, J. R. 2006c. Editorial: towards a theory of project management: the nature of the project, International Journal of Project Management 24: 1-3.

http://dx.doi.org/10.1016/j.ijproman.2005.11.007

Turner, J. R. 2006d. Editorial: towards a theory of project management: the nature of the project governance and project management, International Journal of Project Management 24: 93-95. http://dx.doi.org/10.1016/j.ijproman.2005.11.008

Turner, J. R.; Keegan, A. 2001. Mechanisms of governance in the project-based organization: roles of the broker and steward, European Management Journal 19(3): 254-267.

http://dx.doi.org/10.1016/S0263-2373(01)00022-6

Turner, J. R.; Müller, R. 2003. On the nature of the project as a temporary organization, International Journal of Project Management 21: 1-8. http://dx.doi.org/10.1016/S0263-7863(02)00020-0

Turner, J. R.; Simister, S. J. 2001. Project contract management and a theory of organization, International Journal of Project Management 19: 457-464.

http://dx.doi.org/10.1016/S0263-7863(01)00051-5

Williams, T. 2004. Assessing and building on the underlying theory of project management in the light of badly over-run projects, in PMI Research Conference, 2004, London.

Winch, G. 1989. The construction firm and the construction project: a transaction cost approach, Construction Management and Economics 7: 331-345.

http://dx.doi.org/10.1080/01446198900000032 
Winch, G. 1996. Thirty years of project management - what have we learned?, in The British Academy of Management Conference Proceedings, 1996, Birmingham, UK.

Winter, M.; Smith, C.; Morris, P. W. G.; Cicmil, S. 2006. Directions for future research in project management: the main findings of a UK government-funded research network, International Journal of Project Management 24: 638-649. http://dx.doi.org/10.1016/j.ijproman.2006.08.009

Yung, P. 2009. Institutional arrangements and construction safety in China: an empirical examination, Construction Management and Economics 27(5): 439-450.

http://dx.doi.org/10.1080/01446190902855633

Yung, P.; Lai, L. W. C. 2008. Supervising for quality: an empirical examination of institutional arrangements in China's construction industry, Construction Management and Economics 26(7): 723-737. http://dx.doi.org/10.1080/01446190801998690

Ping YUNG is currently an Associate Professor in Curtin University of Technology, Australia. He has a PhD from University of Hong Kong. He has over five years of industry experience and is a member of Royal Institution of Chartered Surveyors. His main research interest is the application of new institutional economics on project and construction management. 